\title{
INFECTIOUS MEGAENTERON OF MICE
}

\section{DETECTION OF COLIFORM ORGANISMS OF AN UNUSUAL BIOTYPE AS THE PRIMARY CAUSE}

\author{
MASARo NAKAGAWA, RIICHI SAKAZAKI*, TAKESHI MUTO, \\ MANABU SAITO, TOSHIKATSU HAGIWARA AND KIYOSHI IMAIZUMI \\ Department of Veterinary Science, * Department of Bacteriology I, \\ National Institute of Health, Shinagawa-ku, Tokyo 141, Japan
}

(Received: June 23th, 1969)

\begin{abstract}
SUMMARY : A large number of coliform organisms of an unusual biotype was isolated frequently from the intestinal tract and sometimes from the liver and spleen of mice affected with megaenteron (Muto et al., 1969). In contrast, only a few healthy mice harbored the organisms in their guts. When healthy mice were inoculated orally with the organisms, a fatal diarrheal disease, indistinguishable clinically and pathologically from the natural cases, developed consistently in 1-week-aged mice after an 8- to 10-day incubation period. Weanlings aged 4 weeks were also affected but not so severely as sucklings. Bacteria-free filtrate of the intestines of diseased mice failed to affect sucklings by oral administration. Thus, the organisms of the biotype were regarded as the causative agent of megaenteron of mice.
\end{abstract}

\section{INTRODUCTION}

Previous to this publication, Muto et al. (1969) reported a newly discovered disease of mice characterized by thickening of the small or large intestine, associated with severe diarrhea and subsequent death in sucklings aged 2 to 3 weeks, and gave a provisional name "megaenteron of mice" to the disease. In their report, full descriptions of clinical signs and pathological findings of the affected animals were given, but no etiological evidence of the disease was shown.

To investigate the causative agent or agents of the disease, the present authors performed some bacteriological examinations on various organs of mice showing typical symptoms and intestinal lesions. In the course of the investigation, none of known pathogenic bacteria including Salmonella species was found, but coliform bacilli of an unusual biotype were recovered frequently from the intestinal tract and sometimes from the liver and spleen of the sick mice. The present investigation was initiated to examine the pathogenicity of the organisms in mice.

中川雅郎・武藤健・斎藤学・萩原敏且・今泉清（国立予防衛生研究所獣疫部）

坂崎利一 (国立予防衛生研究所細菌第一部) 
Characteristics of the Organisms.

On horse blood agar plates, the coliform bacilli developed non-hemolytic, medium-sized, low convex, smooth, entirely-edged and colorless or rather opaque colonies resembling those of typical Escherichia coli. The colonies on MacConkey agar showed a characteristic central pale pink spot surrounded by colorless periphery. No growth was obtained on SS agar.

All the cultures isolated showed the same morphological, physiological and biochemical properties (Table 1). They were Gram-negative, non-motile and non-

Table 1. Characteristics of the organisms isolated

\begin{tabular}{lllr}
\hline Oxidase & - & Fermentation & acid \\
Nitrate reduction & + & Glucose & + \\
Indol & - & gas & + \\
Hydrogen sulfide (TSI) & - & Cellobiose & + \\
Methyl red & + & Galactose & + \\
Voges-Proskauer & - & Lactose & + \\
Citrate (Simmons) & - & Levulose & + \\
Citrate (Christensen) & + & Maltose & + \\
Gelatin liquefaction & + & Mannose & + \\
Urease & - & Melibiose & + \\
Phenylalanine deaminase & - & Melezitose & - \\
Lysine decarboxylation & - & Raffinose & - \\
Ornithine decarboxylation & - & Rhamnose & + \\
Arginine dihydrolation & + & Sorbose & - \\
K P organic acids & & Sucrose & - \\
$\quad$ Citrate & - & Trehalose & + \\
D-tartrate & - & Xylose & + \\
Mucate & - & Adonitol & - \\
K C N broth & - & Dulcitol & - \\
Motility & - & Erythritol & - \\
& & Inositol & - \\
& & Mannitol & + \\
& & Salicin & $(+)$ \\
& & Esculin & - \\
\hline
\end{tabular}

$+=$ positive, $(+)=$ late positive, $-=$ negative

capsulated rods. They reduced nitrate to nitrite, fermented glucose with gas production, and gave negative reactions in tests for oxidase, hydrogen sulfide production, Voges-Proskauer, phenylalanine deaminase, and growth in cyanate broth. Arginine was dihydrolated within $24 \mathrm{hr}$, while lysine and ornithine were not decarboxylated. They liquefied gelatin, but failed to produce indol, utilize citrate on ammonium agar, and decompose urea. In addition to these properties, all the cultures behaved as follows: arabinose, cellobiose, galactose, levulose, maltose, mannose, rhamnose, trehalose, xylose, mannitol and mucate were fer- 
mented within 1 to 2 days; melezitose, melibiose, raffinose, sorbose, sucrose, adonitol, dulcitol, inositol, esculin and d-tartrate were not attacked; and lactose and salicin were fermented after $72 \mathrm{hr}$ of incubation. These characteristics suggested that the organisms should be included into the genus Escherichia, although some aberrations were found in indol production, gelatin liquefaction and amino acids decarboxylation.

By agglutination and agglutinin-absorption tests using $\mathrm{O}$ and $\mathrm{OK}$ antisera prepared with one of the strains isolated, it was demonstrated that all the strains were of a single serotype.

In $\mathrm{O}$ agglutination tests with antisera of Escherichia $\mathrm{O}$ groups 1 to 146, the cultures boiled at $100 \mathrm{C}$ for $2 \mathrm{hr}$ were agglutinated with $\mathrm{O} 115$ antiserum to $20 \%$ of the homologous titer. On the other hand, a boiled culture of the test strain of Escherichia O115 was agglutinated with the $\mathrm{O}$ antiserum of the organisms in question to $50 \%$ of the homologous titer. From these results of cross-agglutininabsorption tests, it was shown that $\mathrm{O}$ antigenic relationship between the test strain of Escherichia $\mathrm{O} 115$ and the organisms isolated was a, b-a, c.

The living cultures of the biotype were inagglutinable with the corresponding $\mathrm{O}$ antiserum, while they were agglutinated with their OK sera. All agglutinins were removed from the OK serum, when the serum was absorbed with each of the cultures boiled at $100 \mathrm{C}$ for 2 and a half hr. The results indicated that the organisms possessed a $\mathrm{K}$ antigen of $\mathrm{B}$ type.

\section{Isolation of the Organisms from Spontaneous Epizootic.}

Materials and Methods: A mouse colony of DDY strain bred and maintained in our laboratory was examined. The spontaneous outbreak of the disease in this colony was already reported in full detail by Muto et al. (1969). The liver, spleen, kidney, lung, heart-blood and several parts of the intestinal tract with the content of sick or healthy mice diagnosed pathologically were examined for the presence of the organisms by the use of MacConkey agar for the intestinal tract and horse blood agar for the other organs.

Results: Isolation of the organisms from sick or healthy mice is summarized in Table 2. All of the kidney, lung and heart-blood samples examined were sterile, and therefore are not listed in the table. In sick mice, the organisms were isolated frequently from the intestinal tract, at $36.6 \%$ from the duodenum, at $74.3 \%$ from the jejunum and at as high as $93.3 \%$ from the colon. The in-

Table 2. Isolation of coliform organisms of the unusual biotype from diseased and healthy mice

\begin{tabular}{cccccc}
\hline \multirow{2}{*}{ Mouse group } & Liver & Spleen & \multicolumn{3}{c}{ Intestinal tract } \\
\cline { 4 - 6 } & & & Duodenum & Jejunum & Colon \\
\hline Diseased & $27 / 56^{*}$ & $21 / 56$ & $26 / 71$ & $110 / 148$ & $153 / 164$ \\
& $(48.2)$ & $(37.5)$ & $(36.6)$ & $(74.3)$ & $(93.3)$ \\
Healthy & $0 / 97$ & $0 / 97$ & $4 / 133$ & $15 / 254$ & $35 / 289$ \\
& $(0)$ & $(0)$ & $(3.0)$ & $(5.9)$ & $(12.1)$ \\
\hline
\end{tabular}

* Positive/Examined. ( ): Per cent. 
testinal contents of severely affected mice yielded the organisms sometimes in pure culture on the blood agar plate. The organisms were recovered from the liver and spleen of some sick mice, but these individuals also harbored the same organisms in their intestines. The number of the bacteria was usually large in the intestinal tract, especially in the colon, but small in the liver and spleen. Contrary to these findings, healthy mice carried the organisms only in the intestinal tract only occasionally, and the liver and spleen were always sterile.

Muto et al. (1969) described that megaenteron commonly appeared in the small intestine of mice aged 2 to 3 weeks, but as they grew older, development of the lesion was limited to the large intestine. Due to the similarity of pathological features, however, they considered that the lesions which developed at different sites of the intestine may probably have been caused by the same etiological agent or agents. In the present study, therefore, the presence of the organisms in the intestine was examined in relation to the age of mice and to pathological changes of the small and large intestinal tracts. The results are given in Table 3. Neither the organisms nor the lesions were found in 49 suck-

Table 3. Incidence of coliform organisms of the unusual biotype in relation to pathological changes of the intestines and age of mice

\begin{tabular}{|c|c|c|c|c|}
\hline \multirow[b]{2}{*}{$\begin{array}{l}\text { Age of } \\
\text { mouse } \\
\text { (week) }\end{array}$} & \multicolumn{4}{|c|}{ Intestinal lesions } \\
\hline & $\begin{array}{l}\text { Negative in } \\
\text { both small } \\
\text { and large } \\
\text { intestines }\end{array}$ & $\begin{array}{l}\text { Positive in } \\
\text { small intestine } \\
\text { but negative in } \\
\text { large one }\end{array}$ & $\begin{array}{l}\text { Positive in } \\
\text { both small } \\
\text { and large } \\
\text { intestines }\end{array}$ & $\begin{array}{c}\text { Negative in } \\
\text { small intestine } \\
\text { but positive in } \\
\text { large one }\end{array}$ \\
\hline $0-1$ & $0 / 49^{*}$ & & & \\
\hline $1-2$ & $8 / 38$ & $2 / 2$ & & \\
\hline $2-3$ & $4 / 26$ & $10 / 10$ & $9 / 9$ & $21 / 22$ \\
\hline $3-4$ & $6 / 29$ & $7 / 7$ & $4 / 4$ & $5 / 5$ \\
\hline $4-5$ & $4 / 32$ & & & $31 / 32$ \\
\hline $5-6$ & $9 / 29$ & & & $27 / 29$ \\
\hline $6-7$ & $2 / 3$ & & & $13 / 14$ \\
\hline $7-8$ & $4 / 16$ & & & $2 / 3$ \\
\hline$>8$ & $12 / 78$ & & & $16 / 18$ \\
\hline Total & $49 / 300$ & $19 / 19$ & $13 / 13$ & $115 / 123$ \\
\hline
\end{tabular}

* Positive/Examined.

lings within 1 week after birth. Isolation of the organisms became positive from 1 to 2 weeks of age, though no lesion developed in mice of this age. From nearly all mice older than 2 weeks of age with the intestinal lesions, a large number of bacteria was recovered, irrespective of the site of the intestine affected. On the contrary, the majority of unaffected mice did not yield the organisms in their intestines or, if any, the number of bacteria was usually smaller than that of the affected ones. 
Experimental Reproduction of the Disease.

Materials and Methods: Some attempts were made to reproduce experimentally the same disease as the natural infection, using mice aged 1 or 4 weeks obtained from a stock colony of the DDY strain. The colony had been proved to be free from the organisms of this biotype by examinations repeated during a long time. The strain of the biotype used for inoculation had been isolated from the intestinal content of a severely affected mouse and maintained on nutrient agar for about 1 year with four sub-culturings. The inoculum was a growth on $5 \%$ horse blood agar for $18 \mathrm{hr}$ at $37 \mathrm{C}$. To each of 4 -week-old young: mice, 1.5 $\times 10^{8}$ viable cells in $0.25 \mathrm{ml}$ saline were introduced into the stomach by means of a 1-mm diameter vinyl tubing attached to a syringe. Uninoculated control mice were fed with $0.25 \mathrm{ml}$ sterile saline by the stomach tubing. For 1-week-old sucklings, about $1.6 \times 10^{6}$ cells in saline were smeared inside the mouth by a loop of a 2-mm diameter. Sterile saline was inoculated into sucklings of a control group in the same way. The young were placed individually on bedding of wood shavings in a $18 \times 30 \times 11 \mathrm{~cm}$ metal cage, while the sucklings were housed together with litter-mates and an uninoculated mother mouse in one cage. Commercial mouse pellets and tap water were given all the time. The cages and bedding material were never changed during the experimental period. Observation was made till the 14 th day after inoculation, and during the time, the feces of young mice were cultured on MacConkey agar every other day to examine for excretion of the administrated organisms. At the termination of the experiment, all the mice, including the control group, were sacrificed for autopsy.

Results: The results of the experimental infection in both the young and sucklings are summarized in Table 4.

Table 4. Experimental infection with the coliform organisms of the unusual biotype

\begin{tabular}{|c|c|c|c|c|c|c|c|c|c|}
\hline & \multirow{3}{*}{$\begin{array}{l}\text { Group of } \\
\text { mouse }\end{array}$} & \multicolumn{8}{|c|}{ No. of animals } \\
\hline & & \multirow{2}{*}{ Tested } & \multirow{2}{*}{$\begin{array}{c}\text { With } \\
\text { diarrhea }\end{array}$} & \multicolumn{2}{|c|}{$\begin{array}{l}\text { With lesion of } \\
\text { megaenteron }\end{array}$} & \multicolumn{4}{|c|}{ Yielding the organisms } \\
\hline & & & & Jejunum & Colon & Liver & Spleen & Jejunum & Colon \\
\hline \multirow{3}{*}{ 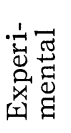 } & Young & 17 & 1 & 0 & 6 & 3 & 3 & 5 & 6 \\
\hline & Sucklings & 25 & 25 & 25 & 25 & 21 & 21 & 25 & 25 \\
\hline & Mothers & 2 & 5 & 0 & 5 & 4 & 4 & 5 & 5 \\
\hline \multirow{3}{*}{ 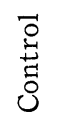 } & Young & 10 & 0 & 0 & 0 & 0 & 0 & 0 & 0 \\
\hline & Sucklings & 16 & 0 & 0 & 0 & 0 & 0 & 0 & 0 \\
\hline & Mothers & 3 & 0 & 0 & 0 & 0 & 0 & 0 & 0 \\
\hline
\end{tabular}

Of 17 young mice inoculated with the organisms, 5 individuals showed negative results in recovery of the inoculated organisms during the entire period of the observation, in clinical symptoms as well as in development of the intestinal lesion. Fecal cultures of 6 other mice yielded tentatively a small number of the organisms for a few days subsequent to administration but turned negative there- 
after. They developed neither symptoms nor lesions. In the other 6 animals, however, the inoculated organisms were recovered from the feces throughout the experimental period. Although counting was not performed, the number of colonies developed on the culture medium suggested that the number of the organisms increased day by day for the first 4 to 6 days and then remained on a constant level. On the 6 th day, mild diarrhea appeared in one of them. The post-mortem examination of these animals revealed typical megaenteron of various degrees in the colon, which was indistinguishable macroscopically and histopathologically from the lesions observed in naturally infected animals. The inoculated organisms were always isolated from the affected intestines in a large number and sometimes from the liver and spleen of the animals. Ten mice of the control group did not excrete the organisms and remained normal in appearance and in pathological examination.

As shown in Table 4, the orally administered organisms always resulted in colonization in the gut of all sucklings and frequently invaded even the liver and spleen. Diarrhea occurred in all individuals 8 to 10 days after administration, showing excretion of profuse yellowish watery materials. The affected mice became severely lethargic and emaciated and hence were sacrificed for autopsy before death. Although the mother mice were not inoculated, they started to excrete loose stool before or after their sucklings were clinically affected, and the organisms appeared in their intestines and often in the liver and spleen. Megaenteron developed in both the small and large intestines in sucklings but it was localized only in the large intestine in the mothers as in the natural epizootic cases. In histopathological examination, these lesions were also indistinguishable from the spontaneous disease. None of the uninoculated controls discharged the organisms nor showed clinical or pathological abnormalities.

Thirty-five strains of the biotype were inoculated into 1-week-aged sucklings of DDY mice in the same way. The results indicated no difference in pathogenicities of these strains. The infected mice developed severe diarrhea and lesions of megaenteron and died around 10 days after inoculation.

\section{Effect of the Bacteria-free Filtrate.}

Materials and Methods: Several parts of the intestines with the contents of some severely affected mice were pooled in phosphate buffered saline and ground with a glass homogenizer to prepare a $10 \%$ emulsion $(\mathrm{w} / \mathrm{v})$. After centrifugation at 6,000 rpm for $1 \mathrm{hr}$, the resulting supernatant was filtered through a sterile filter membrane (Millipore Filter Corp., Bedford, Mass.) of $0.45 \mu$ pore size. One drop or about $0.04 \mathrm{ml}$ of the filtrate, which had been proved sterile by culturing in liquid thioglycollate medium, was inoculated into the mouth of each of 32 DDY mice aged 1 week using a nipette with a fine tip. The mice were observed for 2 weeks and then sacrificed for autopsy. For control groups, 13 mice were inoculated orally with a culture of the biotype by the same method and the other 12 were left untreated.

Results: Clinical or pathological abnormality was observed in none of the mice receiving the filtrate or of untreated controls. They were negative in examination for the organisms of the biotype. On the other hand, the control 
animals inoculated with the culture suffered from severe diarrhea and typical intestinal lesions.

\section{DISCUSSION}

A biochemically unusual strain of Escherichia coli possessing $\mathrm{O} 115 \mathrm{a}$, c antigen was studied for its significance in megaenteron of mice which explosively occurred in our breeding colony. The strain was proved to fulfill Koch's postulates as follows. 1) The organisms were isolated abundantly from the gut of nearly all diseased mice. 2) Only a few healthy mice harbored the organisms in a small number in their intestines. 3) Oral administration of the organisms to healthy mice reproduced the disease indistinguishable clinically and pathologically from the natural epizootic. 4) In addition, the failure in reproducing the disease with a bacteria-free filtrate prepared from the emulsified intestines ruled out some viruses or toxic substance as a causative agent of the disease. Thus, it seems certain that the $E$. coli strain of the unusual biotype is a primary cause of megaenteron of mice.

As far as we know, no report has been published on spontaneous epizootics due to Escherichia coli in laboratory mice, except for an old literature by Sangiorgi (1911), who incriminated a coliform bacillus as the cause of an epizootic disease in mice accompanied by diarrhea. The bacillus, however, showed the ability of indol production, differing from ours. In experimental infection, some investigators succeeded in colonizing Escherichia coli strains pathogenic to human infants in the gut of mice pre-treated with antibiotics, but neither diarrhea nor pathological changes of the organ resulted (Ashburner and Mushin, 1962).

In the United States, Brennan et al. (1965) described an outbreak of diarrhea in laboratory mice associated with catarrhal enterocolitis and thickened colon wall and ascribed the disease to a strain of atypical Citrobacter freundii. However, the intestinal lesions of the affected mice in our study were different from those described by Brennan et al. (1965), as already discussed in the previous paper (Muto et al., 1969). Our mice showed an increase in number of villi, hyperplasia of crypt cells, formation of thickened mucosal folds and lack of inflammatory reaction, but their's were characterized by a catarrhal enterocolitis with accumulation of mucus in the colon.

In spontaneous or experimental infection with the $E$. coli strain of the unusual biotype, the disease developed more frequently and severely in sucklings than in weanlings or adults. Likewise, it is noteworthy that the organisms rarely affected mice younger than two weeks of age, although the experimental infection showed a consistent establishment of the organisms in the gut even in sucklings aged one week. These findings stress the necessity of a certain pre-existing factor for development of the disease. Particularly, the age of animal seemed to be an important factor. In experimental inoculation with $E$. coli into mice, Mushin and Dubos (1965) suggested that the ability of adult animals to withstand the intestinal infection was related to the development in the gastrointestinal tract of a microbiota antagonistic to the inoculated organisms. Fecal bacterial flora of mice usually developed during 1 to 3 weeks of age, although no organisms were detected in feces of 1-day-old mice (Maejima et al., 1967). Susceptibility of the mouse to $E$. 
coli of the biotype was most evident in the age at which fecal flora was in the course of development.

\section{ACKNOWLEDGEMENT}

We are greatly indebted to Dr. Ida Ørskov, International Escherichia Center, State Serum Institute, Copenhagen, for her advice given to the serology of the organisms.

\section{REFERENCES}

Ashburner, F. M. And Mushin, R. (1962): Experimental intestinal coliform infections in mice. J. Hyg. (Camb.), 60, 175-181.

Brennan, P. C., Fritz, T. E., Flynn, R. J. AND Poole, C. M. (1965): Citrobacter freundii associated with diarrhea in laboratory mice. Lab. Animal Care, 15, 266-275.

Maejima, K., Maejima, F., Tajima, Y. AND OkUgi, M. (1967): Viable count of various bacteria in the digestive tract of mice III. Change of viable count of fecal bacteria with age. Bull. Exptl. Animals, 16, 20-25. (text in Japanese)

Mushin, R. AND Dubos, R. (1965): Colonization of the mouse intestine with Escherichia coli. J. Expt1. Med., 122, 745-757.

Muto, T., Nakagawa, M., Isobe, Y., Saito, M., Nakano, T. And Imaizumi, K. (1969): Infectious megaenteron of mice I. Manifestation and pathological observation. Japan. J. Med. Sci. Biol., (in press).

SANGIORGI, G. (1911): Ueber einen coliähnlichen Bacillus als Erreger einer spontanen Epizootie der weissen Mäuse. Zentr. Bakteriol. Parasitenk., Abt. I Orig. 57, 57-59. 